\title{
The Catalytic Activity of Zinc Acetate Supported on Active Carbons and the Pore Structure of the Carriers
}

\author{
Hideaki Muraki, Jun-ichi Kobayashi and Izumi Higuchi \\ Department of Synthetic Chemistry, Faculty of Engineering, \\ Shizuoka University; jôhoku, Hamamatsu-shi, Japan
}

\begin{abstract}
Rates of catalytic reaction, $\mathrm{CH}_{3} \mathrm{COOH}+\mathrm{C}_{2} \mathrm{H}_{2} \longrightarrow \mathrm{CH}_{8} \mathrm{COOC}_{2} \mathrm{H}_{8}$, have been determined by using a number of carrier specimen of active. carbon. They consisted of $\mathrm{A} \sim \mathrm{E}$ and $\mathrm{F}$ series activated by carbon dioxide in various degree, and each of which contained a different amount $f(\mathrm{~g} / \mathrm{g}-\mathrm{C})$ of zinc acetate as catalyst. Pore distributions of supported catalysts as well as carriers have been determined by means of the mercury porosimeter and in terms of the sorption isotherms of benzene at $0^{\circ} \mathrm{C}$. Although the pore structures of carriers were quite different from one another as shown in Fig. 1, the analysis of data given in Tables 1 and 2 exhibited clearly that most of zinc acetate would be deposited only in the micropores. It has been confirmed again that catalytic activity $k^{0}$ referred to unit weight of the carrier increased linearly with $f$ values and then became constant $k_{i}{ }^{0}$ above a limiting value $f_{i}$, as shown in Figs. 3 and 4. Fig. 5 shows clearly that in $F$ series, as the activation degree $w$ of specimens increased, $f_{i}, k_{i}{ }^{\circ}$ and the micropore volume $\phi_{\text {micro }}$ of carrier increased.
\end{abstract}

Fig. 6 shows that $f_{i} \sim k_{i}{ }^{0}$ relation for all the carriers was linear within the error of $10 \%$ except some carriers of lower activation degree.

Therefore, the catalytic activity was attributed to zinc acetate deposited in micropores of carrier and the effect of diffusion on the rate could not be found, revealing the macro-micro pore model of granular active carbon, described in previous paper, to be valid.

\section{アルカリ水溶液における水酸化カルシウムと糖との錯体の生成}

\author{
(1972 年 5 月 26 日 受 理)
}

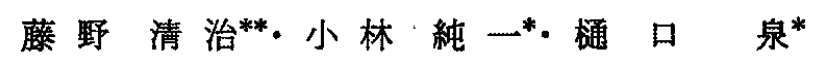

\begin{abstract}
グルコースやキシロースの上5な楉の水溶液に拈ける $\mathrm{CaO}$ の異常に高い溶解性は $\mathrm{Ca}(\mathrm{OH})_{2}$ の可溶性錯体の形成 飞基つくことを、つぎのよらな奉験によって明らかにした。グルコース水溶液に特ける CaO の溶解度はクルコース 源度に比例して增加する。それらの溶存モル此忙 $1: 1$ である。このモル比は、 $\mathrm{Ca}(\mathrm{OH})_{2}$ 觉飽和したグルコース溶液 K土タノールを加えて析出させた固体試料についての化学分析の結果からす確譀された。

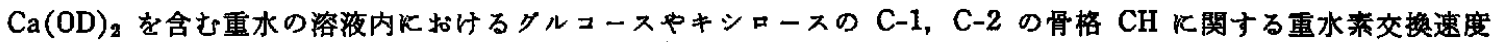
は NaOD を含む溶液内のそれと比較してかなり速いことが、それぞれの NMR スペクトルの経時变化から明らかと なった。また D-グルコースや D-フルクトース水溶液の揟光性は少量すっの CaO の溶解飞とすない直線的に減少す る。これらの実験結果から、フルカリ溶液内に扎いて錯体はェンジオール型の炭水化物が配位した水酸化カルシウム からなっていることを示した。このよ5な錯体搆造は，上K述べた固体の錯体についての IR スペクトルがこの構造 に適った特性吸取を示す事実からも支持することができた。
\end{abstract}

\section{1 緒 言}

ホルムアルデヒドを水溶液内でアルドール縮合させ糖類すなわ らホルモースを生成する反応に括いて，もっとも有効な塩基触媒 として用いられているすのは酸化カルシウム $\mathrm{CaO}$ または水酸化 カルシウム $\mathrm{Ca}(\mathrm{OH})_{2}$ である。その触媒反応は古くから多くの研 究1)が行なわれているが， $\mathrm{CaO} や \mathrm{Ca}(\mathrm{OH})_{2}$ の水飞対する溶解度

* 静岡大学工学部合成化学科, 浜松市城北

** 現在 三菱モンサント化成株式会社，四日市市東邦町
があまり大きくないために，䅗濁状態のまま反応を行ならのが通 常である。ところが，反応の進行にともない， $\mathrm{CaO}$ の溶解がみ られ，後の報告です詳述するよらに，とくにホルモースの自触媒 的な急激な発熱反応䎲ともなって，溶解現象すまたいちじるしい， ことが観察される。著者らはこれらに着目した結果, アルデヒド あるいは楉の水溶液仙 $\mathrm{CaO}$ がかなり多量に溶解することを定

1）たとえば， E. Fisher et al., Ber., 22，359(1889)；23, 370(1890) ; E. Pfeil et al., ibid., 85, 293(1952); Ann. Chem., 641, 121(1961). 
量的飞確認した。さらにこの $\mathrm{CaO}$ を溶解した榶の水澄液はそれ

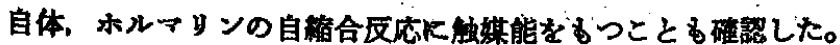

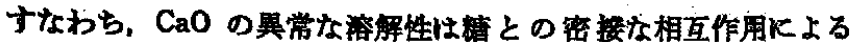
すのであり，ホルモース生成反応任重要な関連があることが明ら かである。

多量に溶解した $\mathrm{CaO}$ が，溶液中でとのような状態で存在して

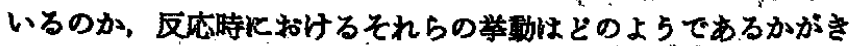
わめて興味が深い。その存在状態を究明することは，すなから反 応機構の解明飞大をく役立つるのと思われる。実際の反応では， ホルモースが種々の糖の混合物であり，検索が简単にいかかい。 したがってここで性，単一の糖として主にグルコースをえらび， $\mathrm{CaO}$ との相互作用を究明しよらと試みたるのである。

サッカロース水溶液がアルカソ士数金属の水酸化物を比較的よ

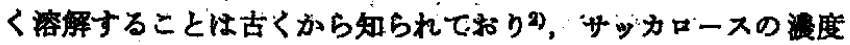

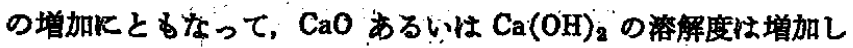
ている。しかし難溶性の沈股物の問題なと指摘されており，定 量的飞红不明の点するる。またグルニース溶液化おける $\mathrm{CaO} の$

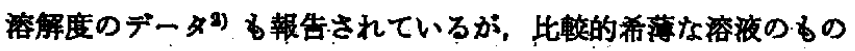
であり，測定範囲が十分でない。さらに瀑厚な溶液での定量的な 湌討が望まれる。

この研究では溶解度のみでなく，その榶-カルシウム系の均一

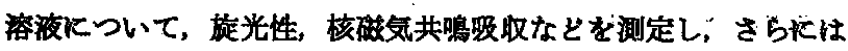
溶液から析出した固体武料の赤外吸収スベクトル，化学分析など の测定す併用して，究明を行ない，糖とカルシウムとが形成する 錯体について多くの知見を得ることができたのでここに報告す ろ。

\section{2 实糇}

\section{1 試 䓪}

試璘はすべて市服特級品をそのまま用いた。 $\mathrm{CaO}$ はその溶解 速度を考虑してなるべく微粒状が望ましく，270メッシュ以上に 粉确して用いた。用いた糖は主として Dーグルコースである。そ の他，比較のために D-フラクトース，D-キシャーズなどを一部 К併用した。

\section{2 測 定}

糖の水溶液に $\mathrm{CaO}$ を溶解し試料溶液を調製するさい，一般に 不溶部の口過が必要である。口過は二酸化炭素の影響をさけるた めに空素気流中で行なった。

つぎのよらな種々の測定実験に応しててれぞれ溶液試料をつく った。

2.2.1 溶解度の測定 : 種々の濩度のグルコース水溶液をつく りそそれと等モル以上の $\mathrm{CaO}$ を加えて室温で 12 時間らりまぜ る。不溶部を口過し, 得られた口液について, 溶解カルシウム淟 度を EDTA 滴定により求めた。またその溶液の $\mathrm{pH}$ は東亜電波 製 HM-5 A，pH メーターKより測定した。

2.2.2 旋光度測定 : あらかしめ既知惯度のグルンース水溶夜 を調製し,これK少量ずつの $\mathrm{CaO}$ を溶解させていき，旋光度の 变化を測定する。実呀は $5^{\circ} \mathrm{C}$ の低温で行なった。測定機器は日立 製旋光計 S 141-1 型である。不溶部があるときには口別して除

2) A. Seidell, "Solubilities of Inorganic and Metal Organic Compounds", D. Von Nostrand Company, Princeton, New Jersey (1958) p. 639.
く。溶液のカルシウム瀑度は别に EDTA 滴定Kより求めた。 としてフタクトースを用いた湓合す同様である。

2.2.3 NMR 澌定: 重水比ル゙ルコースを溶解し, 糖の $\mathrm{COH}$

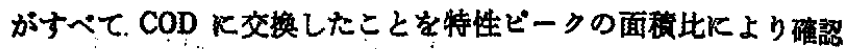
してから，グルコースと等モルの $\mathrm{CaO}$ を加光て溶解させる。 ${ }^{3} 5^{\circ} \mathrm{C}$ 飞呿いて，NMR スペクトルの経時変化を調へ，糖の $\mathrm{CH}$ $\rightarrow \mathrm{CD}$ の重水素交換速度を湘定した。洌定は日立 Perkin Elmer

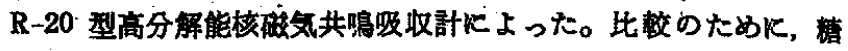
としてキシロースを用いた埸合、ならびKアルカリとして NaOD

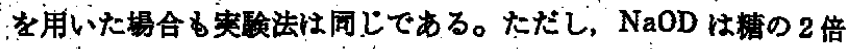
モル囬を用いた。

2.2.4 IR 澌定 : 所定湛度のグルコース本溶淮に $\mathrm{CaO}$ を小過

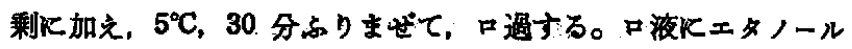
を加え，析出した沈殿をとり出し，空温で娍王乾燥したるのを試 料とする (以後 [Ca-Gl] と略記する)。日本分光 (JASCO) IR-S 型赤外分光計を用い，ヌジョール法により测定した。また別に [Ca-G1] の化学分析を行ない，カルシウム含有量を垌へた。

2.2.5 その他比較のためにホルムアルデヒドの水溶液に対す る $\mathrm{CaO}$ の溶解珄ならびKその溶夜の検討るいくつか行なった。

\section{3 結 果}

\section{1 䅦水溶液における $\mathrm{CaO}$ の溶解度 $\left(1^{\circ} \mathrm{C}\right)$}

$\mathrm{CaO}$ の溶解度は糖の濃度の增加にとるなっていちしるしく増加 する。図 1 火活種々の濃度》のグルコース水溶液に括ける $\mathrm{CaO}$ の

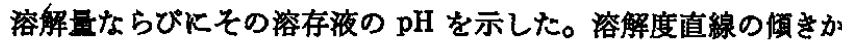

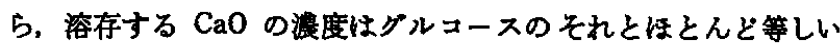
ことがわかる。綎軸とのわずかな切片值は $\mathrm{CaO}$ 単独の溶解度 $2.16 \times 10^{-2} \mathrm{~mol} / \mathrm{l}$ にほ

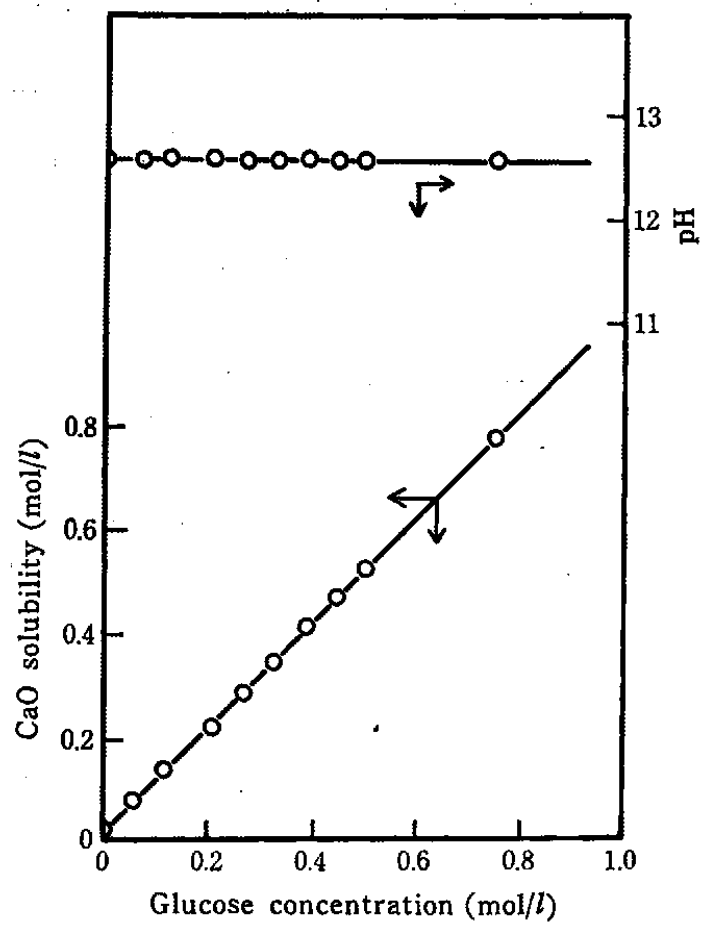

Fig. 1 Solubility of $\mathrm{CaO}$ in aqueous solution of glucose and $\mathrm{pH}$ of the alkaline solution vs. the concentration of glucose, at $18^{\circ} \mathrm{C}$

3）高濃度のざいは容積变化の補正を行なってある。 


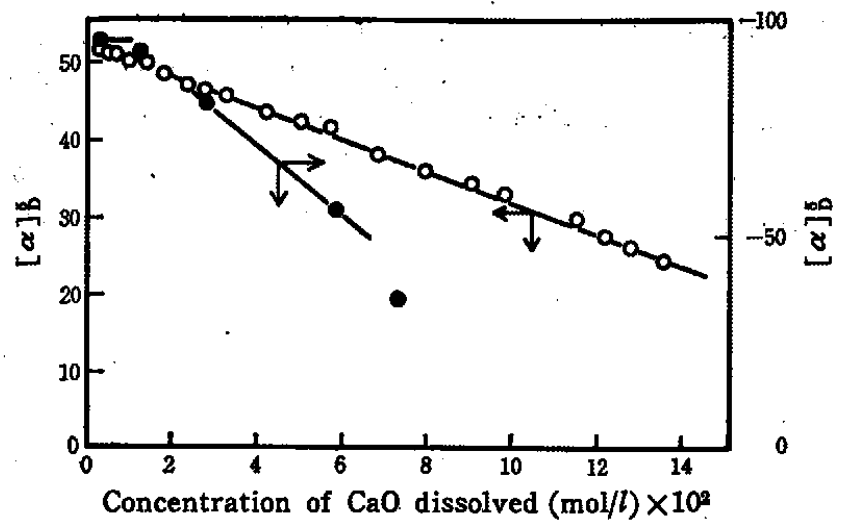

Fig. 2 Optical activities of D-glucose and D-fructose changing with concentration of $\mathrm{CaO}$

$O$ : D-Glucose solution, $16.20 \times 10^{-2} \mathrm{~mol} / \mathrm{l}$

: D-Fructose solution, $12.71 \times 10^{-2} \mathrm{~mol} / \mathrm{l}$

以上Kも増加することが明らかである。したがってグルコースと 溶解カルシウムとはモル比 $1: 1$ の錯体を形成していることが確 認される。また $\mathrm{CaO}$ の異常な溶解量にるかかからず, 糖一カルン ウム溶液の $\mathrm{pH}$ は 12.55 とほぼ一定値を示し，これは水酸化カル シウム単独の飽和水溶液のそれに等しいことが注目される。

\section{2 旋 光 性}

D-グルニースの水溶液に $\mathrm{CaO}$ を少量才゙つ溶かしていくときの

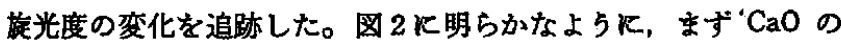
わずかな添加で $\alpha, \beta$ の平衡值 $[\alpha]_{D} \div 52^{\circ}$ になるが，その後は $\mathrm{CaO}$ 量の増加にともない，ほほ值線的に漸減する。D-フラクト 一スを用いた場合す同じような項向がみられる。糖の旋光性にと

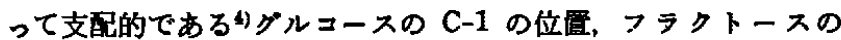

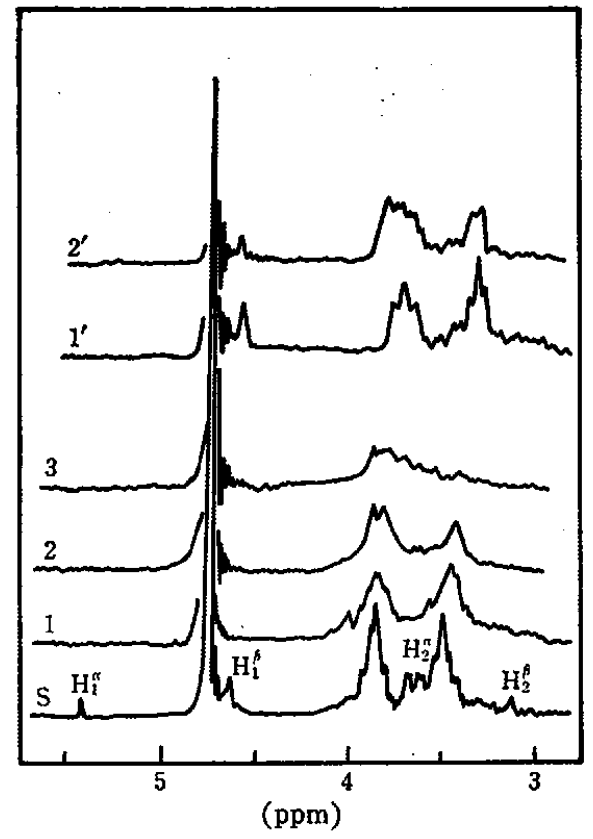

Fig. 3 NMR spectra of glucose changing in time in alkaline solution

$\mathrm{S}:$ Glucose- $\mathrm{D}_{2} \mathrm{O}$ solution, $2.50 \mathrm{~mol} / \mathrm{l}$

1,2 and $3:$ At 5,30 and 235 minutes after adding equimole of $\mathrm{CaO}$ to $\mathrm{S}$.

$1^{\prime}$ and $2^{\prime}$ : At 30 and 270 minutes after adding twofold moles of NaOD to $\mathrm{S}$.
C-2 の位揞に対して，溶解したカルシウムが直接的に作用して， 変化を与えているものと考えてよいであろう。

\subsection{NMR スペクトル}

グルコースならびKキシロース重水溶液について， $\mathrm{CaO}$ を溶解 したときの变化ならびた NaOD を溶解したときの变化をそれぞ れ図 3，4 Kそれぞれ示してある。それぞれの糖はアルガの共 存によって，CH 特性吸収》が幅広になり，かつ時間ととるに減 少する。その減少量は水の特性喛収帯の増大となっであらわれ る。これから糖の CH が重水策交換を受けることが明らかであ り，その交換速度は喛収帯面穦の経時变化から测定することがで きる。

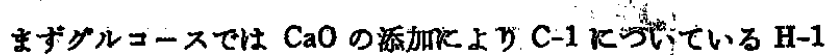

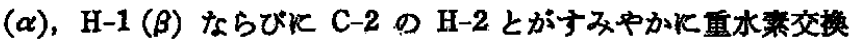
されて消失しているのがわかる。一方， NaOD の掦合：H-1 の 減少がみられるが，交换速度は燵く，5時間以上経ってるいまた

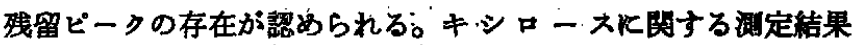
す,グルヌースの畦合とよく俔ている。 $\mathrm{H}-1$ は $\mathrm{CaO}$ 添加により すみやかに重水菜交換される。その他の特珄ビークは楅広になり

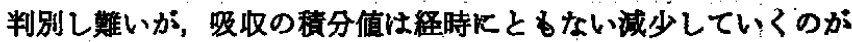

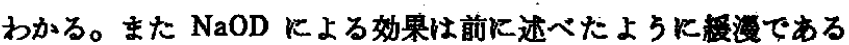
ことがわかる。なお， $\mathrm{CaO}$ の場合は各特性吸収のシフトは少ない が、 NaOD:で浚收帯がかなり高磁場側ヘシフトしているのが注 目される。

以上の測宽から，各組文合わせに括ける榶 $\mathrm{CH}$ の重水素交换速

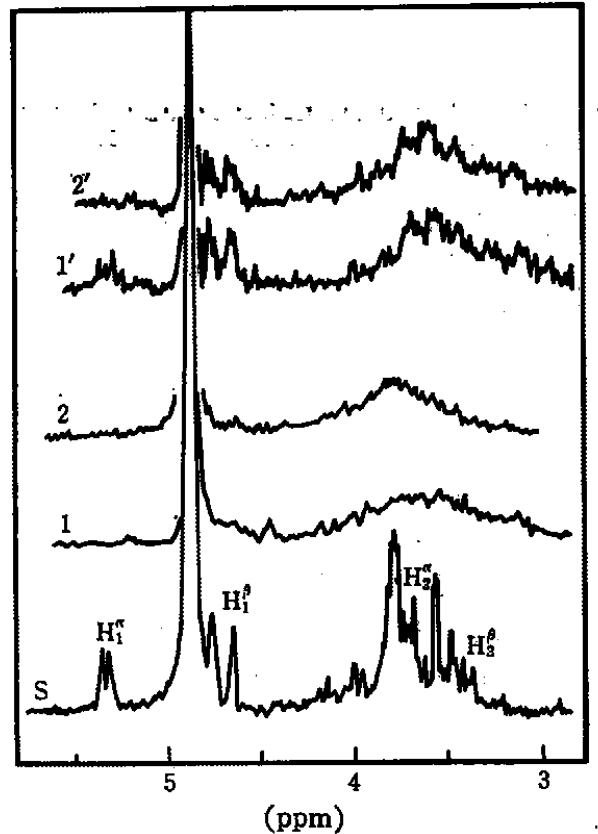

Fig. 4 NMR spectra of xylose changing in time in alkaline solution

$\mathrm{S}$ : Xylose- $\mathrm{D}_{2} \mathrm{O}$ solution, $1.29 \mathrm{~mol} / \mathrm{l}$

1 and 2 : At 5 and 25 minutes after adding equimole of $\mathrm{CaO}$ to $\mathrm{S}$.

$1^{\prime}$ and $2^{\prime}$ : At 5 and 20 minutes after adding twofold moles of $\mathrm{NaOH}$ to $\mathrm{S}$.

4) C.S.Hudson, J.Amer. Chem. Soc., 31, 66(1909).

5) R. U. Lemieux, J. D. Stevens, Can. J. Chem., 44, 249 (1966). 


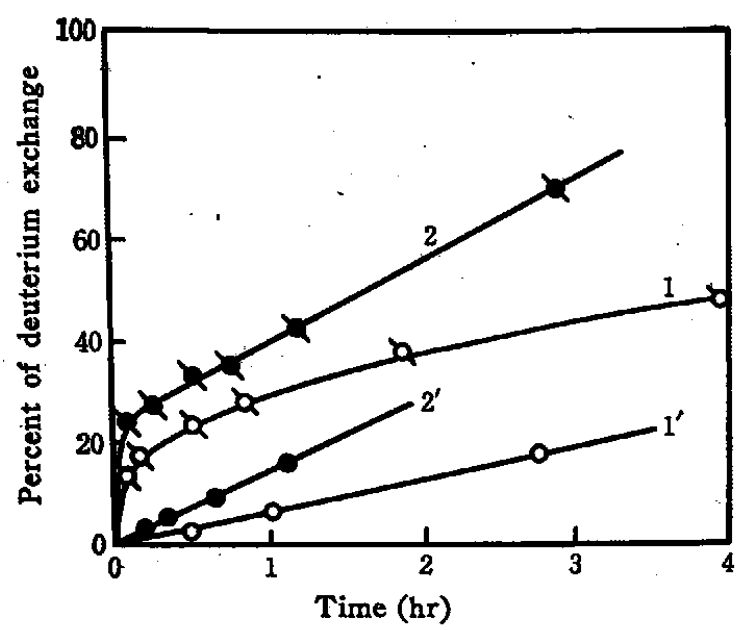

Fig. 5 Rates of deuterium exchange for the skeletal CH of glucose or xylose

$1:(\mathrm{Ca}-\mathrm{Gl}), 1^{\prime}:(\mathrm{NaOD}-\mathrm{Gl})$

$2:(\mathrm{Ca}-\mathrm{Xy}), 2^{\prime}:(\mathrm{NaOD}-\mathrm{Xy})$

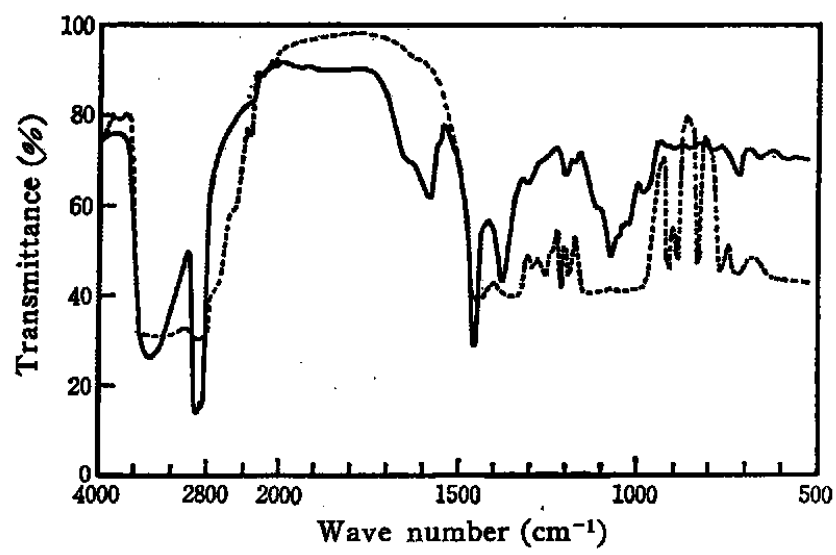

Fig. 6 IR spectrum of [Ca-GI] complex

Solid line : [Ca-Gl] complex

Dotted line : glucose alone

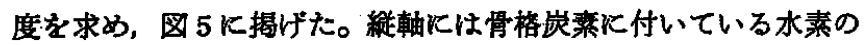
交換パーセントを示す。グルコース㤌 $\mathrm{CaO}$ の添加に上り，初期 飞急速な交換が起こる。この初期交換量恃骨格 $\mathrm{H}$ の全数化対する C-1 とC-2 のHの数の比 $2 / 7=0.286$ K注相当する。その後 はゆるやかな交換速度がつつく。この後期の速度は NaOD の場 合とはぼ同しである。すなわち $\mathrm{CaO}$ 共存の場合, 糖の C-1, C-2 のHは非常飞交換しやすいが，NaOD の場合はとくに交換しやす いHはない。一方，キシロースの場合もまったく同じ交換現象が みられる。急速な初期交換量は骨格Hの全数に対する比 $2 / 6=$ 0.333 K近い割合になり，C-1，C-2 のHが交換されやすいこと が明らかである。この CH 交換性は，Ca-糖錯体が関連してくる ホルモース生成反応汇おいて重要な性質と思われるが，別の報告 で考察することにする。

\subsection{IR スペクトル}

2.2.4 とよってつくったグルコースと $\mathrm{Ca}(\mathrm{OH})_{2}$ との共沈体 [Ca-Gl] ならびにグルコース単独の赤外吸收スペクトルを図6K 示した。ヌジョールの吸收は $2919,2861,1458,1378 \mathrm{~cm}^{-1}$ の 4 本である。また [Ca-Gl] 蛙よびグルコースに共通にあらわれる 吸収帯は，3600 2200 $\mathrm{cm}^{-1}$ の $\mathrm{OH}$ 找上び $\mathrm{CH}$ の伸縮振動,
$1450 \sim 1200 \mathrm{~cm}^{-1}$ の C-C 伸樎, $1150 \sim 950 \mathrm{~cm}^{-1}$ の C 0 伸絠握 動であるのがわかる。両者でいちじるしく巽なる暖取带は 1800 $\sim 1500 \mathrm{~cm}^{-1}$ の領域と $1000 \sim 700 \mathrm{~cm}^{-1}$ の領域にみられる。まず 前者の領域においては、グルコース単独で㤌ピラノース環を形成 しているために $\mathrm{C}=0$ の伸縮振動飞基づく吸収が現われないと思 われる。しかし [Ca-Gl] では $1635 \mathrm{~cm}^{-1}$ および $1585 \mathrm{~cm}^{-1} \mathrm{~K}$ 明白な吸収があらわれている。これらの吸取は $\mathrm{C}=0$ の伸縮振動 域 $1900 \sim 1600 \mathrm{~cm}^{-1}$ 巧よび C=C 伸綟振動域 $1700 \sim 1500 \mathrm{~cm}^{-1} \mathrm{~K}$ 属し，しかる比較的低波数側にシフトしていることを考慮する と， $\mathrm{C}=0 ， \mathrm{C}=\mathrm{C}$ の伸縮振動炕それぞれ㷌属できるるのと考えられ

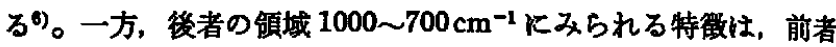
とは逆に，グルコース単独の埸合にみられると゚ラノース環の特性 吸収が，[Ca-G1] ではすべて消失していることである。たと代 $917 \mathrm{~cm}^{-1}$ はピシノース環の振動 $(\alpha, \beta), 894 \mathrm{~cm}^{-1}$ は $\mathrm{C}-1 \sim \mathrm{H}$ （ $\beta$ ）変角振動， $834 \mathrm{~cm}^{-1}$ 忙 $\mathrm{C}-1 \sim \mathrm{H}(\alpha)$ の変角振動飞㷌属され る)。

上記のような結果からる，カルシウムとグルコースとが錯体を 形成していることが明らかである。錯体の形成にとるない，グル コースのピラノース環は開裂し，C-O，C-C の二重結合性が增大 するすのと結論してよいであろら。

\section{5 [Ca-G1] の化学組成}

2.2.4 でつくった [Ca-Gl] 中に含まれるカルシウムを, EDTA 滴定法により分析して $15.6 \mathrm{wt} \%$ を得た。グルコースと水酸化 カルシウム $\mathrm{Ca}(\mathrm{OH})_{2}$ とが $1: 1$ のモル比に結合していると仮定 するとカルシウム含有量の計算値は $15.8 \%$ であり，実験値とよ く一致する。[Ca-Gi] が $1: 1$ 組成の錯体として単離されたすの であることは，この化学分析の結果からす明らかである。

\section{6 ホルムアルテヒド水溶液に対する $\mathrm{CaO}$ の溶解}

糖水溶液に括けると同様にホルマリンに対してる $\mathrm{CaO}$ はかな りよく溶解する。 $4 \%$ ホルマリン中の溶解度が純水の場合の 7 倍 程度はあり，ホルマリンの濃度の増加にともなってその溶解度も 增加することが容易化確喼された。しかしあまりカルシウムが過 剩になると不溶性の沈殿を生ずるために溶解度の定量的な測定は

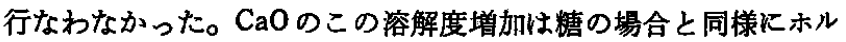
ムアルデヒドとの錯体生成沉起因するすのであろう。この錯体生 成についてはつぎのような実験によっても確かめられた。ホルマ リンK $\mathrm{CaO}$ を飽和に近く溶解し $50^{\circ} \mathrm{C}$ に昇温すると白色固体の 析出物を生ずる。 $0^{\circ} \mathrm{C}$ で口過，洗浄し，隇圧乾燥する。析出試料 の化学分析は, $\mathrm{Ca}(\mathrm{OH})_{2}$ と $\mathrm{HCHO}$ のモル比が $1: 2.23$ であり, 試料作製法の半定量性を配虑すると錯体は $1: 2$ の化学組成とみ なされる。また試料の赤外吸収スペクトルは $1600 \mathrm{~cm}^{-1}$ その他に $\mathrm{C}=0$ 伸縮振動の吸収があらかれ，ホルマリンのメチレングリコ ール $\mathrm{CH}_{2}(\mathrm{OH})_{2}$ の吸収とは明らかに異なっている。したがって 2 分子のホルムアルデヒドの $\mathrm{C}=0$ 基は $\mathrm{Ca}(\mathrm{OH})_{2}$ に直接配位し て錯体を形成していると考えられる。

$$
4 \text { 考察 }
$$

\section{1 錯体構造}

溶解度, 旋光性, NMR, IR, 化学分析などの以上の絬果は7

6) K. Nakamoto, "Infrared Spectra of Inorganic and coordination compounds", Wiley Interscience (1963) p. 244.

7）中西香爾，“赤外線吸収スペクトル”, 南江堂 (1960) p. 40. 
ルカリ溶液において溶存カルシウムが糖と錯体を形成することを 明らか実証したものである。かつ，それらを考察して錯体の構 造を推定することができる。溶解度，化学分析，などの量論的関 伱から，錯体組成がモル比 $1: 1$ であることは薙いるないる。

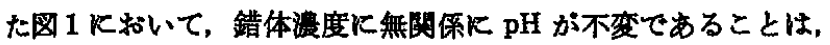
錯体生成の反応自体に $\mathrm{H}^{+}$あるいは OH- のイオン軼は介入しな いことを示す。溶液のアルカリ性は $\mathrm{Ca}(\mathrm{OH})_{2}$ の塩基性によるる のであるが, $\mathrm{Ca}(\mathrm{OH})_{2}$ の $p K_{b}$ から考えて $\mathrm{pH}>12$ では溶存カル シウムの化学種は $\mathrm{Ca}^{2+}$ の形ではなく主として非解䨋の $\mathrm{Ca}(\mathrm{OH})_{2}$ になっていると推定される。したがって錯体形成反応はつぎのよ らな単純なるのであろう。Gl は一般に榶を表わす。

$$
\mathrm{Gl}+\mathrm{Ca}(\mathrm{OH})_{2} \longrightarrow\left[\mathrm{Gl}-\mathrm{Ca}(\mathrm{OH})_{2}\right]
$$

錯体中で $\mathrm{Ca}(\mathrm{OH})_{2}$ の形になっていることの妥当性は, 化学分析

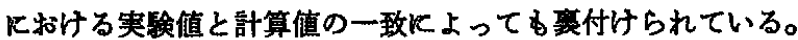

一方，糖についていえば，旋光性の直線的滅少，NMR Kたけ る重水素交換珄の結果から考えて，糖の C-1 および C-2 の炭案 の位膡が結合に関与していることが明らかである。かつ IR にお けるピラノース環の消失ならびに C-0，C-C の二重結合性の增 加をすあわせて考虑すると，糖の結合は ene-diol 型になってい ると推定される。錯体構造はつぎのようであろう。<smiles>[R]C1O[C@H](O)[C@@H](O)O1</smiles>

もちろんRは一般に $\mathrm{C}_{n} \mathrm{H}_{n+1}(\mathrm{OH})_{n}$ である。一般に糖の enediol 型はアルカリ性に拈いて生じやすく，糖のアルドース，ヶ トース間の異性化における中間体として考えられている9。この 錯体では $\mathrm{Ca}(\mathrm{OH})_{2}$ 人の配位により,より安定化したすのと考え てよいであろう。なお C-1, C-2 の Hの重水素交換の特異性から

8）後の報告では，別の組成比の錯体について言及することが あるが，本実験条件下では少なくとる $1: 1$ の錯体組成が かなり安定であると考えている。

9) J. C. Speck, Jr., Advan. Carbohydrate Chem., 13, 63 (1958).
みると、二重結合性は，C-C間反局在化しているのでなく，C-0, C-C間俳局在結合を㫴る方がより妥当であると思われる。IR の結果るそれを支持していると思われるがその結合性については 別の榙会に詳諭したい。

\section{2 錯体と螌媒反㐫}

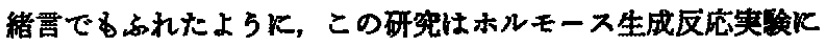
拈ける $\mathrm{CaO}$ の異常溶解性火端を発している。 $\mathrm{CaO}$ の溶解が核と の錯体形成に基つくことは本実験の結果から明らかとなった。さ らに 3.6 です述べたよら飞 $\mathrm{Ca}(\mathrm{OH})_{2}$ はホルムアルデヒドとる作 用をるち類似の錯体を形成することが推定される。ホルムアルデ. ヒドとの錯体は 2 分子の $\mathrm{C}=0$ 基がとるに配位するのK対して, 糖との錯体は $\mathrm{C}=0$ 基の配位がより安定な ene-diol 型への移行 K結果し，一般には 1:1 組成となるのが特徽といえる。

これらの錯体が，アルカリ性隹おけるホルモース生成反心たよ び, Cannizzaro 反応飞とって重要であり，その反応機構飞密接 に関連してくることはいらまでるない。

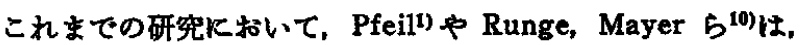
Cannizzaro 反応火おける中間体として $\mathrm{Ca}(\mathrm{OH})_{2}$ とホルムアルデ ヒド 2 分子との錯体を考えているし; また, ene-diol と $\mathrm{Ca}(\mathrm{OH})_{2}$ との相互作用にはとくにふれてはいないけれとも，Kusin'11およ

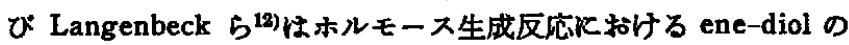
重要な促進作用を指摘している。

カルシウム鍺体関する本実験の種なの測定結果は，以上のよ らな反応機構に推穿されていた従来の知見に夙して，さらに明白

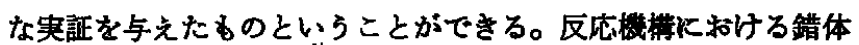
の役割，すなわち反応中間体としての錯体の举動あるい惜体が 演ずる触媒作用などについての詳細な検討はつぎの報告で述べる ことにする。

終りにのそみ，糖に関しましていろいろとご数授をいただきま した静岡大学工学部猪川郎数授に厚く感謝いたします。

（1971 年 4 月，第 28 回你媒討論会（一部）講演）

10) K. Runge, R. Mayer, Ann.Chem., 707, 161(1967).

11) A.Kusin, Ber., 68, 619, 1495, 2169(1935).

12) W. Langenbeck et al., Naturwissenshaften, 30, 30 (1942) ; Angew. Chem., 61, 186(1949).

Complex Formation from Calcium Hydroxide and

Carbohydrate, in Alkaline Solutions

\author{
Kiyoharu Fujino, Jun-ichi Kobayashi and Izumi HrguchI \\ Department of Synthetic Chemistry, Faculty of Engineering, \\ Shizuoka University; Jôhoku, Hamamatsu-shi, Japan
}

The abnormally high dissolution of $\mathrm{CaO}$ in aqueous solution of carbohydrate such as glucose or xylose is attributed to the complex formation by the following facts. Solubility of calcium hydroxide in glucose solutions is proportional to the concentration of glucose, as their molar ratio is one to one. The value of the molar ratio is further confirmed by chemical analysis of the solid sample, deposited by pouring ethanol in the glucose solution saturated with $\mathrm{Ca}(\mathrm{OH})_{2}$.

NMR spectra changing with time show clearly that the rates of deuterium exchange of the skeletal $\mathrm{CH}$ at $\mathrm{C}-1$ and $\mathrm{C}-2$ positions of glucose or xylose in $\mathrm{D}_{2} \mathrm{O}$ solution containing $\mathrm{Ca}(\mathrm{OD})_{2}$ are rapid enough as compared with those in $\mathrm{D}_{2} \mathrm{O}$ solution containing $\mathrm{NaOD}$. Thus, it can be concluded that the complex is made of calcium hydroxide coordinated the carbohydrate in enediol type in alkaline solution. 
Such a structure of Ca-complex is also supported lby experimental results that the optical activities of $\mathrm{D}$-glucose or $\mathrm{D}$-fructose solutions decrease linearly with the amount of added $\mathrm{CaO}$ and that the IR spectra of the solid complex show characteristic absorptions suitable to this structure.

\title{
水酸化カルシウムの可溶性錯体触媒による 均一系ホルモース生成反応
}

(1972 年 5 月 26 日受理)

\author{
藤 野 清 治**.小林 純 一*。桶、口 泉*
}

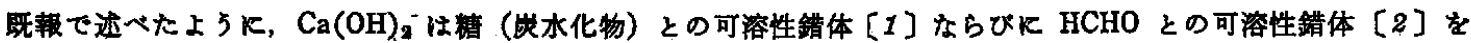
つくる。その錯体を含を均一フルカリ性の HCHO 溶液に和いて，ホルモース生成反応と並発する Cannizzaro 反応 の雨者の速度を $40 \sim 60^{\circ} \mathrm{C}$ の範国で定量的に测定した。グルュースキキシャースなどの榶との錯体〔1〕を含む反応

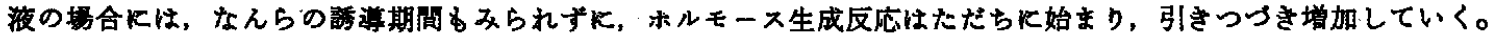
糖を含まない反応液の場合，才なわち錯体〔2〕の场合，一般にこの誘迸期間は長時間にわたってあらわれ，そこで

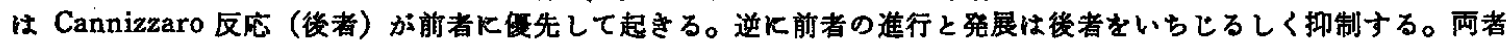

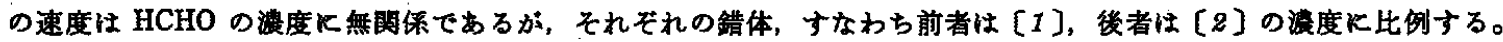

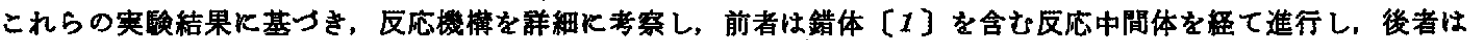
錯体〔2]を経て進行することを明らかKした。さらに,フルカリ土類金属の種類あるいは糖の種類の異なる錯体 [1]kよる実験結果を比较検討して，それらの触媒活性は錯体形成能の序列と密接に夙連するであろうことを示し た。
\end{abstract}

\section{1 粕言}

塩基性触某化上りホルムアルデヒドから糖類すなわちホルモー スを生成する反応杜 Boutherow (1861) 以来, 古くから多くの 研究1)の゙かなれてきている。この種の糖合成代関しては水野の 総説引すある塩基触媒としてはアルカリ土類金属あるいはフル カリ金属の水酸化物なとの無機塩基が一般に用いられ，また最近 ではピリジン、ピコリンなとの有機盐基についてる研究)が進め られている。これらのなかです，この縮合反応にすぐれた触媒と して㕕く用いられているのは，水酸化カルシウム $\mathrm{Ca}(\mathrm{OH})_{2}$ ある いは酸化カルシウム $\mathrm{CaO}$ である。

ホルモース生成反応関する従来の研究により，反応機搆，触 媒の有効性なと，多くの知見が明らかにされてきたが，定量的な 研究例が之しく，定泩的論旨のなかにはいまだ不明の点も少なく ない。とくに CaO また注 $\mathrm{Ca}(\mathrm{OH})_{2}$ を用いる㬰験では水水対す

* 静岡大学工学部合成化学科, 浜松市城北

** 現在 三悲モンサント化成株式会社, 四日市市東邦町

1) E. Fischer et ai., Ber., 22, 359(1889); 23, 370(1890).

2) W. Langenbeck et al., Naturwissenschaften, 30, 30 (1942); Angew. Chem., 61, 186(1949).

3) E. Pfeil et al., Chem. Ber., 85, 293(1952); Ann.Chem., 641, 121(1961).

4) R. Mayer et al., Ann.Chem., 635, 145(1960); 707, 161 (1967).

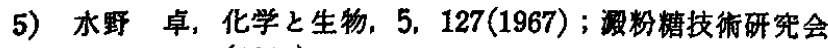
報, 37, 31(1968).
る溶解度があまり大きくないので通常は䇣濁状態のまま反応が行 なわれる。この不均一系に加えて，Cannizzaro 反応の並発と， ホルモース生成にとるな $5, \mathrm{CaO}$ の異常な溶解とが起きるため 飞，反応速度を定量的に解析するのが難かしく，反応機構の考察 る推定の域を脱していないのが現状である。最近 Weiss ら゙は均 一飞近い系で反底解析を行なっているが，用いたカルシウム触媒 はスラリー状であり， $\mathrm{Ca}(\mathrm{OH})_{2}$ の溶解性にはふれていない。

既報7では, この $\mathrm{Ca}(\mathrm{OH})_{2}$ の異常溶解性に着目し, 糖または アルデヒドの水溶液に沏ける $\mathrm{CaO}$ の溶解度を定量的に検討し， かつその溶液について種々の検討を行ない，糖またはアルデヒド と $\mathrm{Ca}(\mathrm{OH})_{2}$ との錯体形成を明らかにした。この錯体形成を逆に 利用すれば，糖やアルデヒドの共存においては，溶存するカルシ ウムをかなり高灙度にたるつことが可能である。またこのカルシ ウム錯体は反応の主役であり，とくに楉との錯体はホルモース生 成反応の触媒としていちじるしい促進作用があることを確衿し た。

この研究では，このカルシウム錯体触㜀を用いてホルモース生 成反応を均一系で行ない，Cannizzaro 反応とともに反応速度を 定量的に解析することができた。既報に挌ける錯体に関する知見 をもとに反応機構，触媒作用機搆に考察を加之，多くの知見を明 らかにすることがでさた。

6) A. H. Weiss, R. B. Lapierre, J. Sphaira, J. Catal., 16. $332(1970)$

7）藤野清治，小林純一，桶口泉，日化，1972，2287. 